ISSN 0258-7122 (Print), 2408-8293 (Online)

Bangladesh J. Agril. Res. 43(3): 513-524, September 2018

\title{
GENETIC VARIATION AND HERITABILITY FOR FOLIAGE YIELD AND YIELD COMPONENT TRAITS IN EDIBLE Amaranthus cruentus [L.] GENOTYPES
}

\author{
O. T ADENIJI ${ }^{1}$
}

\begin{abstract}
The field experiment with nine Amaranthus cruentus genotype was conducted, to estimate the magnitude of genetic variability, heritability and genetic advance for leaf yield and contributing traits of amaranth genotypes during 2013 and 2017 cropping seasons. Field experiment was carried out in a randomized complete block design with three replications between 2013 and 2014 cropping season in Jalingo Taraba state. Data were collected on branches/plant, leaves/plant, leaf length, lead width, leaf fresh weight, leaf dry weight, marketable foliage yield, non- marketable foliage yield and plant height. Analysis of variance revealed highly significant mean squares $(\mathrm{P}<0.01)$ among the genotypes tested for all the traits investigated. Thus indicating presence of high variability for foliage yield and yield traits. The PCV value was greater than GCV for all traits; however, GCV values were near to PCV values for the traits like leaf width, plant height branches/plant indicating high contribution of genotypic effect for phenotypic expression of such characters. High heritability coupled with high genetic advance per percent of mean reflect the presence of additive gene action in the expression of these traits, and improving of these traits could be done through simple selection.For multiple traits, AM 45 outperformed other genotypes for leaves/plant, fresh weight of leaves, plant height, and branches/plant.While AM 42 performed best for foliage yield (t/ha) and branches/plant.
\end{abstract}

Keywords: Amaranth cruentus, Genotypic and phenotypic coefficient of variation, genetic variation, heritability, and marketable foliage yield.

\section{Introduction}

Amaranth belongs to the family Amarantheaceae, which include 650 genera and 850 species which are widely distributed in the tropical and temperate regions of the world. The genus Amaranthus, is a native to different parts of North, Central, and South America. It is mostly monoecious inflorescences bearing both male and female flowers (Trucco and Tranel, 2011). A. cruentus [L.] is diploids with chromosome number $2 \mathrm{n}=32$, but occasionally it can be 34 (Chan and Sun, 1997). Amaranth is an important high value indigenous vegetable in sub Saharan Africa, particularly important crop for developing countries (Smith and

${ }^{1}$ Department of Crop Science and Horticulture, Federal University, Oye Ekiti, Nigeria. 
Eyzaguirre 2007). It is characterized by a high protein content of $12.5 \%-18 \%$ with a well-balanced amino acid composition and high lysine and methionine contents (Pospišil et al., 2006). One cup of amaranth leaves that are cooked, boiled, and drained contains $90 \%$ vitamin $\mathrm{C}$ daily value requirement, $73 \%$ vitamin A, $28 \%$ calcium and $17 \%$ iron (Smith and Eyzaguirre 2007). The vitamin composition of the plant is higher than those reported for Aspilia africana, Bryophyllum pinnatum (Lam.) Oken, Vernonia amygdalina, Eucalyptus globulus L. and Ocimum gratissimum L. (Alabi et al., 2005). Amaranths leaves and stems are used as food in Southeast Asia and Equatorial Africa and can compete with spinach leaves in terms of protein content (van Le et al., 1998). The particularity of amino acid profile of A. cruentus leaves is its methionine and lysine levels, which are the limiting amino acids in most plant proteins (Fasuyi 2007). Amaranth exhibit $C_{4}$ photosynthetic pathway, great amount of genetic diversity and phenotypic plasticity. It is a quantitative short-day plant, which is an advantage in the subtropics, where the generative stage is delayed during summer. Amaranths performed best on fertile, well-drained alkaline soils (pH 6) with a loose structure. Vegetable amaranth is cultivated anytime provided water is not limiting. Its cultivation for leaf is profitable during dry season compared to rain fed conditions. Vegetable amaranths grow well at day temperatures above 25 ${ }^{0} \mathrm{C}$ and night temperatures not lower than $15{ }^{\circ} \mathrm{C}$. Shade is disadvantageous except in cases of drought stress. The mineral uptake inAmaranthus cruentus is very high (Grubben, 2004).

In Amaranthus cruentus there is an urgent need for genetic improvement to enhance foliage leaf yield and quality characters. Improvement in foliage yield requires knowledge of the magnitude of variation in available germplasm, interdependence of quantitative traits on leaf yield, extent of environmental influences, heritability and genetic gain. Genetic variability is important for selection of parents with transgressive segregation (Patro and Ravisankar, 2004). Information on genetic variability and availability of commercial varieties of Amaranthus cruentus genotypes is limited. Therefore, there is a need to generate information on genetic variability, heritability, and genetic advance to estimate the progress of breeding program in future. Progress and gain from selection in any breeding programme depend upon the magnitude of useful variability present in the population and the degree to which the desired traits are heritable. Heritability estimate of a character is important for plant breeder, because it provides information on the extent to which a particular character can be transmitted from the parent to the progeny (Allard, 1960; Poehlman and Sleper, 1995; Syukur et al., 2012). Similarly, genetic advance is important because it shows the degree of the gain obtained in a character from one cycle of selection. High genetic advance coupled with high heritability estimates offers the most suitable condition to decide the criteria of selection (Allard, 1960; Poehlman and 
Sleper, 1995; Syukur et al., 2012). Efficiency of selection in breeding programme relies upon association between traits. Correlation between leaf yield and its related traits could improve the efficiency of selection in amaranth breeding. Leaf yield is a complex quantitative character and controlled by several genes interacting with the environment. The extent of genetic variation and genotypes agronomic performance of Amaranthus cruentus remains largely rudimentary indicating untapped potential for research. Currently, there are few commercial varieties of Amaranth cruentus released into the cropping systems in Nigeria.

The objectives of this study are to evaluate the magnitude of variation for leaf yield and yield component traits under short cycle harvest, estimate genetic variation and heritability for leaf yield and yield component traits and determine association between leaf yield and yield component characters.

\section{Materials and Methods}

\section{Location, Site characteristics and Germplasm}

This research was conducted at the research farm, National Open University of Nigeria, Jalingo, Nigeria (Lat $8^{\circ} 47^{\prime} \mathrm{S}$ and Lon $11^{\circ} 09^{\prime} \mathrm{E}$,altitude of masl) in May, 2013 and 2014. Jalingo is characterized by monomodal rainfall regime. The rainfall season starts in April/May, thereafter the cold and dry season (November to January). The hottest month is between February to March/April. The soil type is clay loam with $\mathrm{pH}$ between 6.0 and 6.5. Eight amaranth genotypes (AM 42, AM 38-2, AMTZ 01, AM 40, AM 50, Ex-Zimbabwe, AM 25, AM 45 and a popular local cultivar (AM local) received from the gene bank of The World Vegetable Center were used for field investigations. The entries are homogeneous for phenotypic traits.

\section{Experimental design and Data collection}

Field experiments were established in July, 2013 and 2014. Nine amaranth genotypes were grown in a randomized complete blocks design with three replications. Sunken beds were made at $1 \mathrm{~m} \times 2 \mathrm{~m}$, each bed was separated by alley of $1 \mathrm{~m}$. A total of 9 beds constituted a replicates. Each bed was treated with $4 \mathrm{Kg}$ of matured farmyard manure. Prior to field establishment seeds were tested for viability. Thereafter $10 \mathrm{~g}$ of viable seeds was uniformly spread on each vegetable bed. The experiment was rain fed with occasional manual irrigation. Weeding was carried out manually and frequently to maintain a weed free plots. Harvesting was done by uprooting at 4 weeks after sowing. Amaranth plants in each net plot $(1 \mathrm{~m} \mathrm{x} 1 \mathrm{~m})$ were used to determine leaf yield and yield contributing traits. Branches/plant, leaves/plant was estimated by counting branches or leaves on ten randomly picked amaranth plants. The leaf 
length and width were measured with a meter rule on five randomly picked leaves per plant. Plant height $(\mathrm{cm})$ was measured with a meter rule on ten randomly picked plants per entry. Foliage yield was separated into marketable foliage yield and non-marketable yield. The non-marketable foliage yield comprised weak and yellowish green plants, and portion of the lower stem and roots. The marketable foliage yield (t/ha) and non-marketable yield ( $\mathrm{t} / \mathrm{ha}$ ) were estimated from marketable foliage yield/plot and non-marketable foliage yield/plot measured on weigh balance $(\mathrm{Kg})$. At harvest three plants were randomly picked per plot, thereafter all leaves/plant were excised, counted and weighed on electronic weigh balance to obtain the fresh weight of leaves. The fresh leaves were oven dried at $32^{\circ} \mathrm{C}$, until a constant weight was obtained. Dried leaves were weighed on sensitive electronic weight balance to obtain leaf dry weight.

\section{Data analysis}

Homogeneity of residual variances was tested prior to a combined analysis over years using Bartlet's test (Bartlett, 1937). The data collected were homogenous and showed normal distribution. The Genotype (G) and Year (Y) were considered to be fixed-effects, while replications was considered as random effect. The combined analysis of variance was performed using a mixed model on plot means combined across years for all traits using PROC - GLM procedure of Statistical Analysis System (SAS) software version 9.2 (SAS, 2008). Thereafter treatment means were tested with Duncan multiple range testing (DMRT) at 5\% probability levels (SAS, 2008). Correlation coefficients between traits was computed using PROC CORR procedure of SAS (2008).

\section{Estimates of variance components}

The variability present in genotypes on A. cruentus was estimated by phenotypic and genotypic variance and coefficient of variation. The phenotypic and genotypic variance, genotypic and phenotypic coefficients of variation were estimated based on formula Syukur et al. (2012) as follow:

$\sigma^{2} \mathrm{G}=[(\mathrm{MSG})-(\mathrm{MSE})] / \mathrm{r}$

$\sigma^{2} \mathrm{P}=\left[\sigma^{2} \mathrm{G}+\left(\sigma^{2} \mathrm{E} / \mathrm{r}\right)\right]$,

Where: $\sigma^{2} \mathrm{G}=$ Genotypic variance; $\sigma^{2} \mathrm{P}=$ Phenotypic variance; $\sigma^{2} \mathrm{E}=$ environmental variance (error mean square from the analysis of variance); MSG $=$ mean square of genotypes; $\mathrm{MSE}=$ error mean square; $\mathrm{r}=$ number of replications.

Genotypic coefficient of variation $(\mathrm{GCV})$ was calculated as $=\left[\left(\sigma^{2} \mathrm{G}\right)^{1 / 2} \mathrm{X}\right] \times 100$;

While Phenotypic coefficient of variation $(\mathrm{PCV})$ was computed as $=\left[\left(\sigma^{2} \mathrm{P}\right)^{1 / 2} / \mathrm{X}\right]$ $\times 100$, 
Where: $\sigma^{2} \mathrm{G}=$ Genotypic variance; $\sigma^{2} \mathrm{P}=$ Phenotypic variance; is grand mean of a character.

Estimation of heritability in broad sense heritability $\left(\mathrm{h}^{2}\right)$ of the all traits were calculated according to the formula as described by Allard (1960) as follow:

$\mathrm{h}^{2}{ }_{\mathrm{bs}}=\left[\left(\sigma^{2} \mathrm{G}\right) /\left(\sigma^{2} \mathrm{P}\right)\right] \times 100$

Where: $h^{2} b=$ heritability in broad sense; $\sigma^{2} \mathrm{G}=$ Genotypic variance; $\sigma^{2} \mathrm{P}=$ Phenotypic variance.

Genetic advance (GA) was determined as described by Johnson et al. (1955): GA $=\mathrm{K}(\sigma \mathrm{P}) \mathrm{h}^{2}$, where: $\mathrm{K}=$ the selection differential $(\mathrm{K}=2.06$ at $5 \%$ selection intensity); $\sigma \mathrm{P}=$ the phenotypic standard deviation of the character; $\mathrm{h}^{2}=$ broad sense heritability. The genetic advance as percentage of the mean (GAM) was calculated as: $\operatorname{GAM}(\%)=\mathrm{GM} / \mathrm{X} \times 100$, where: $\mathrm{GAM}=$ genetic advance as percentage of the mean, $\mathrm{GA}=$ genetic advance, and $\mathrm{X}=$ grand mean of a character.

\section{Results and Discussion}

The analysis of variance for foliage yield and component traits combined across years (Table 1) showed significant $(\mathrm{P} \leq 0.05)$ mean squares for branches/plant, marketable foliage yield $(\mathrm{t} / \mathrm{ha})$, non-marketable foliage yield $\left(\mathrm{tha}^{-1}\right)$, fresh weight of leaves/plant, leaf dry weight/plant, plant height, leaf length and leaf width. The year effect recorded statistically significant $(\mathrm{P} \leq 0.05)$ mean squares (leaves/plant, marketable foliage yield $\left(\right.$ tha $\left.^{-1}\right)$, non-marketable foliage yield $\left(\right.$ tha $\left.^{-1}\right)$, leaf fresh weight, leaf dry weight and plant height) and insignificant $(\mathrm{P} \geq 0.05)$ mean squares for branches/plant). The genotype by year interaction had significant $(\mathrm{P} \leq 0.05)$ mean squares for leaves/plant, marketable foliage yield (tha ${ }^{-1}$ ), fresh weight of leaves/plant, dry weight of leaves/plant, plant height and leaf length, and insignificant mean squares for branches/plant, non-marketable leaf weight and leaf width.

The number of branches/plant ranged from 5 to 7, AM 25and AMTZ 01 outperformed other genotypes for this trait (Table 2). Leaves/plant was low (5) in AM 38-2, but high (8.60-8.68) in AM 25 andAM 45 respectively. Other genotypes recorded values intermediate between the two extremes. Over years marketable foliage yield (t/ha) ranged from $11.50 \mathrm{t} / \mathrm{ha}$ and $22.67 \mathrm{tha}^{-1}$ (Table 2). AM 42, AMTZ 01 performed best (22.67 tha ${ }^{-1}$ and $\left.22.37 \mathrm{t} / \mathrm{ha}\right)$ followed by AMLOC. High and consistent leaf yield over years indicated that these genotypes are promising for leaf yield and further testing in other locations. Non-marketable foliage yield was high in AM 42 followed by AMTZ 01 and AM 45. High proportion of non-marketable foliage yield may be associated overcrowding associated with broadcasting of seeds, competition for available nutrients and insect pests attack. Marketable foliage yield recorded in this study was low 
compared to those reported for vegetable amaranth accessions harvested by uprooting in East Africa (AVRDC, 2002, 2008; Oluoch et al. 2009). The weight of fresh leaves/plant was high (38.2 g) in AM 45, while AMTZ 01 recorded $36.33 \mathrm{~g}$, and $36.1 \mathrm{~g}$ in AM 25. In contrast, entries with high estimates for fresh weight of leaves recorded low values for leaf dry weight. This suggests high proportion of water compared to dry matter. Best genotypes for leaf dry weight are AM 25, AM 38-2 and AM LOC. Plant height is short $(10.33 \mathrm{~cm})$ in AM 38-2, on the other hand AM 45 and AM 42 are tall $(28 \mathrm{~cm}$ and $25 \mathrm{~cm}$ at 4 weeks, respectively). The leaves of AM 42 are long $(9.00 \mathrm{~cm})$, followed by AM $45(8.37$ $\mathrm{cm})$ and AMLOC $(7.70 \mathrm{~cm})($ Table 2). The leaves of Ex-Zimbabwe are narrow $(1.55 \mathrm{~cm}$ ).In contrast AM 42, AM 45 and AMTZ 01 had wider leaves (range from $6.16 \mathrm{~cm}$ to $6.83 \mathrm{~cm}$ ). AM 42 recorded high leaf yield, and also exhibited highest mean performance for leaf length and width (Table 2). For multiple traits, AM 45 was best for leaves/plant, fresh weight of leaves, plant height. While AM 42 performed best for leaf yield (t/ha) and branches/plant (Table 2).

Variability played an important role in crop breeding program, it is prerequisite to understand variability in the population and partitioning into genotypic, phenotypic and environmental effects. Variability is also important for the selection of superior genotypes in crop improvement programs. Agronomic traits are quantitative in nature, and interact with environment under study, so partitioning the traits into genotypic, phenotypic, and environmental effects is essential to find out the additive or heritable portion of variability. The estimates of genetic components and heritability are presented in Table 3 . For all leaf yield and yield components traits estimates of genotypic variance are low in magnitude compared to their corresponding phenotypic variance. Similarly the estimates of phenotypic coefficient of variation (referred hereafter as PCV) were in most cases greater than their respective genotypic coefficient of variation (referred hereafter as GCV) for all the traits indicating the impact of the environmental factors towards expression of traits. Similar results were also reported by Syukur and Rosidah (2014) in pepper. Moderate estimate of PCV was recorded for plant height, fresh weight of leaves, leaf length, leaf width and non-marketable foliage yield, and moderate GCV was recorded for leaf dry weight. This implies that improvement in this trait under selection may be achieved up to a reasonable extent. Low PCV (branches/plant, leaves/plant and leaf length) and GCV (branches/plant, marketable foliage yield, fresh weight of leaves, leaves/plant) for traits implies that chances of getting substantial gain under selection are likely to be less for these traits. Environmental coefficient of variation ranged between from 0.10 (leaf dry weight) and 0.21 (non-marketable leaf weight t/ha). High PCV (marketable foliage yield, non-marketable foliage yield and dry leaf weight and leaf width) indicates the magnitude of improvement in these traits through selection to enhance the potentiality of leaf yield. Similar result were also observed in Amaranth tricolor (Shukla and Singh, 2000). However, GCV was 


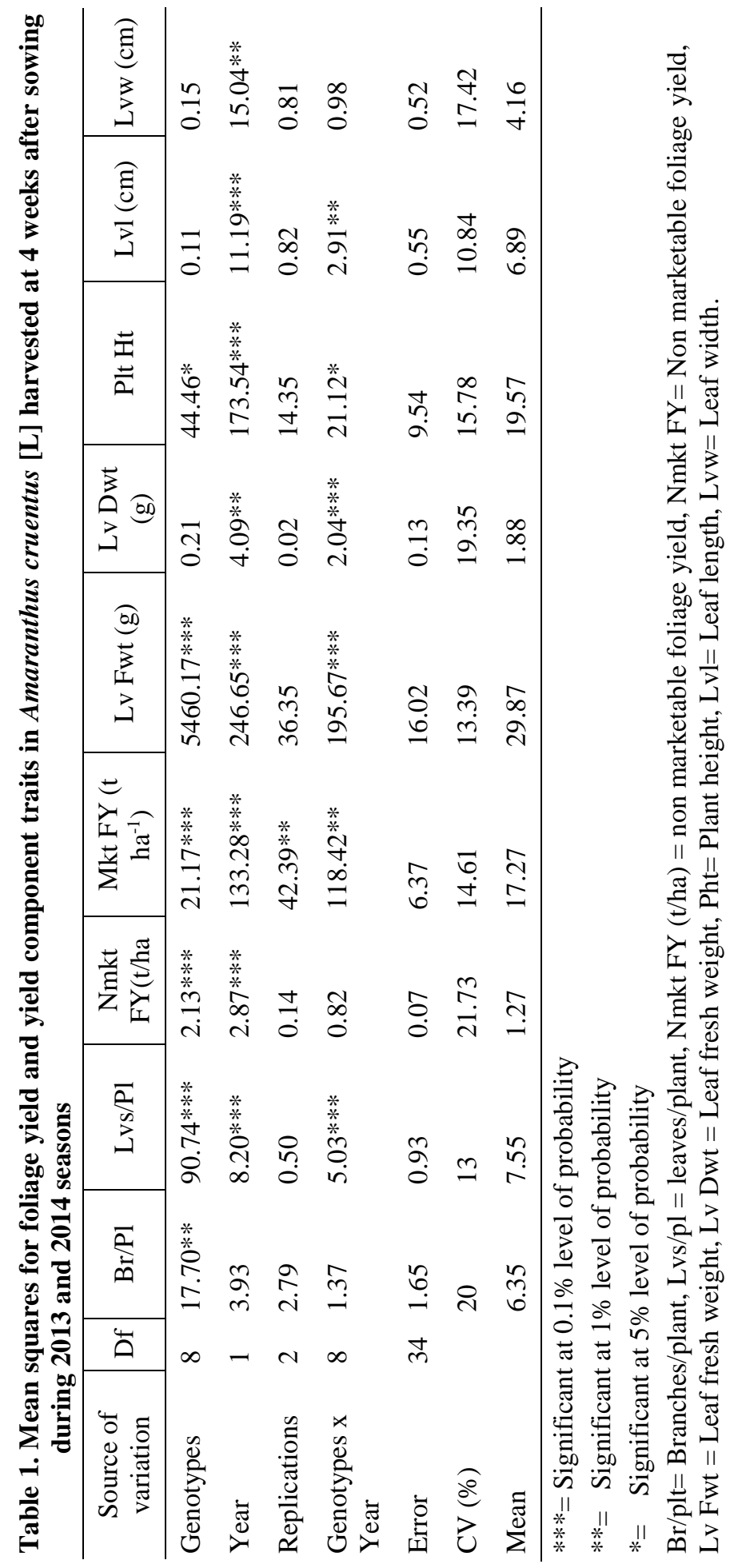




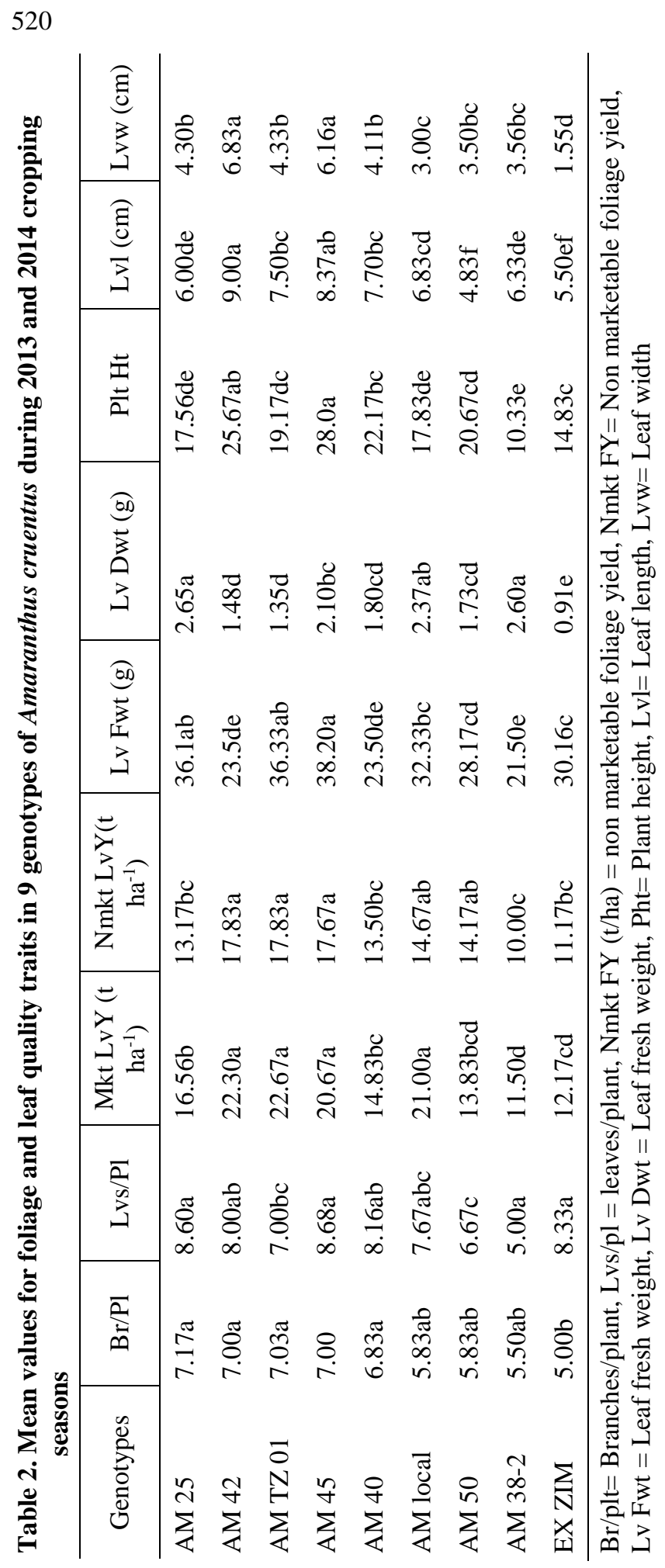

ADENIJI 
GENETIC VARIATION AND HERITABILITY FOR FOLIAGE YIELD

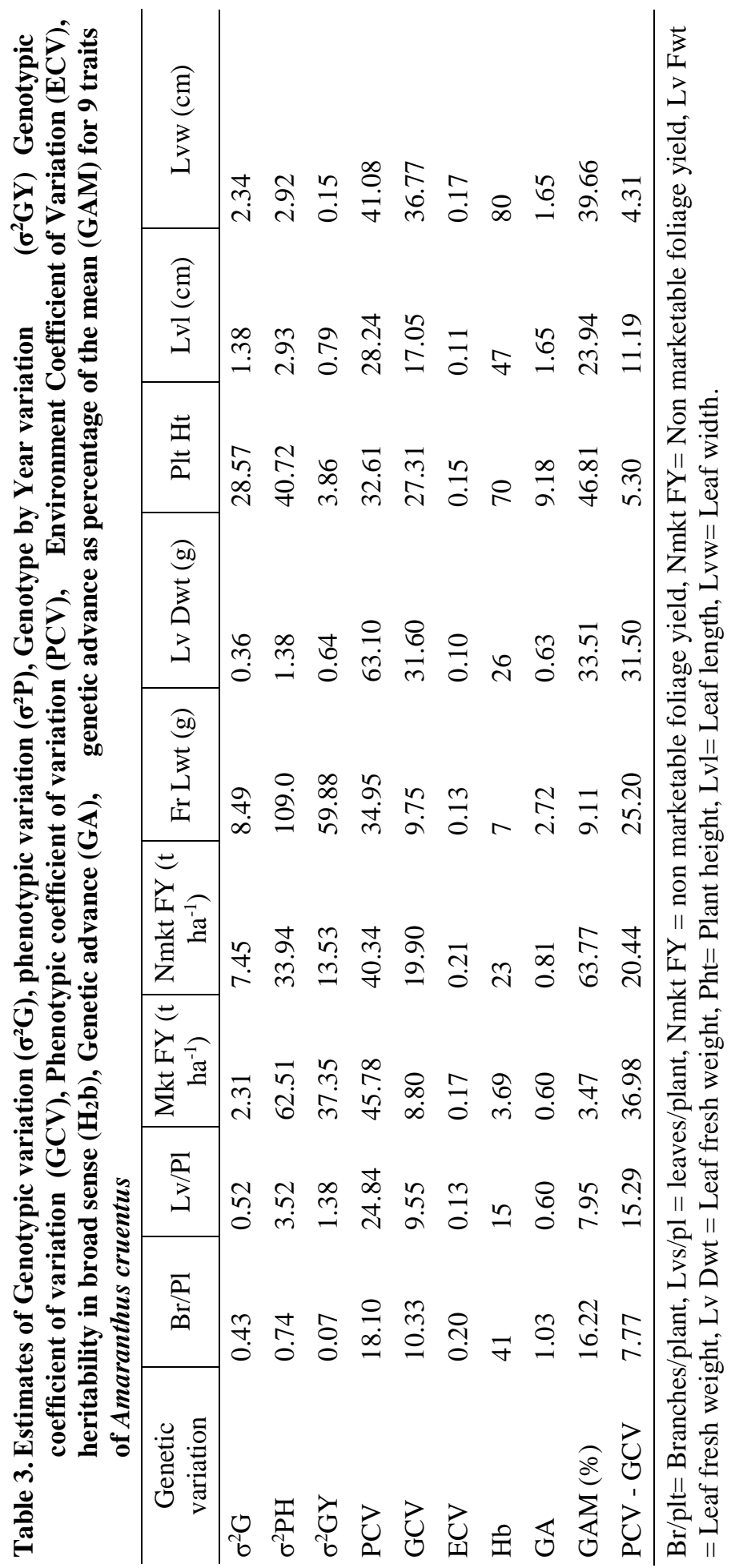


not near to PCV for all traits except leaf width, plant height and branches/plant. This indicates a high contribution of environmental effects compared to genotypic effect for phenotypic expression of these traits. A large difference between GCV and PCV was observed for marketable foliage yield (t/ha) and leaf dry weight, this indicates a large contribution of environmental factors, in addition to genetic effects in the expression of these traits. Findings reported in this investigation are similar to previous reports by Sharma et al. (2010) in bell pepper. Preponderance of genetic variability among the tested genotypes showed that yield improvement through selection was possible in Amaranth cruentus. The efficiency of selection depends on the magnitude of genetic variability and inherent heritability of the traits.

Singh (2001) had noted that heritability values greater than $80 \%$ were very high, values from $60-79 \%$ were moderately high, values from $40-59 \%$ were medium, and values less than $40 \%$ were low. Accordingly, heritability estimates was low for leaves/plant, marketable yield, non-marketable foliage yield, fresh weight of leaves and leaf dry weight (Table 3 ). High heritability estimates were recorded for leaf width (70\%) and plant height (60\%). Findings in this study are consistent with previous report of Sharma et al. (2010) in Amaranth tricolor.Phenotypic traits having very high heritability indicates relative small contribution of the environment factors to the phenotype, and selection for such characters could be fairly easy due to high additive effect. In addition, medium heritability estimates wererecorded for branches/plant and plant height. While leaves/plant, marketable foliage yield, non-marketable foliage yield, fresh weight of leaves and leaf dry weight had low heritability estimates. In contrast, Shukla et al. (2004) reported that high heritability for foliage yield, branches/plant and plant height in Amaranthus tricolor harvested by cutting fresh leaves at 3 weeks after planting, and at 15 days thereafter. In this investigation it was observed that some traits recorded moderate to high heritability, with low genetic advance. These traits may be governed by non-additive gene action, which limits the scope for phenotypic improvement through selection

Branches/plant recorded negative and significant correlation coefficient with leaf width (Table 4). This indicated that phenotypic improvement in the number of branches will not complement leaf width among the genotypes. The leaves/plant recorded positive and significant correlation coefficient with marketable foliage yield ( $\mathrm{t} / \mathrm{ha}$ ), non-marketable foliage yield ( $\mathrm{t} / \mathrm{ha}$ ) and leaf fresh weight $(\mathrm{g})$. This implied interdependency among these traits as more leaves are produced per plant, a corresponding increase in marketable foliage yield is expected. Interdependency associated with non-marketable foliage yield can be reduced through uniform distribution of seeds, use of organic fertilizers and adoption of good agricultural practices designed for vegetables. The marketable foliage yield showed positive and significant correlation coefficient with non-marketable leaf yield, and positive though insignificant correlation coefficients with leaf length, 
leaf width and leaf dry weight. Further, weight of fresh leaves recorded positive and significant correlation coefficient with leaves/plant. These result suggest that selection and improvement of leaves/plant will enhance leaf fresh weight. Significantly negative correlation coefficient in the association between leaf dry weight and branches/plant showed that improvement in leaf dry weight will not enhance branches/plant. Considering high genotypic and phenotypic variances along with GCV and PCV values, high heritability coupled with GA five traits (branches/plant, plant height, leaf width and leaf length) could be selected.

\section{Conclusion}

The study showed considerable magnitude of variation for foliage yield and yield traits in Amaranthus cruentus genotypes. The magnitude of phenotypic and genotypic variation, phenotypic and genotypic coefficient of variation recorded implied the scope on which improvement can be achieved in this species. Leaf width, plant height and branches/plantare highly heritable. These traits could be used as good criteria for selection in the amaranth improvement because these traits had moderate genotypic coefficient of variation, high heritability and genetic advance as percent of the mean. AM 25, AM 42, AMTZ 01 and AM 45 performed best for individual and multiple traits and are recommended for evaluation in multiple environment.

\section{References}

Alabi, D, M. Onibudo N. Amusa. 2005. Chemicals and nutritional composition of four botanicals with fungitoxic properties. World Journal Agricultural Science. 1(1):84-88.

Allard, W. 1960. Principles of Plant, pp. 83-108 Breeding John Willey and Sons. Inc. London.

AVRDC. 2002. Asian Vegetable Research and Development Center Annual Report 2002, Taiwan.

AVRDC. 2008. A traditional food crop becomes attractive with the East African seed sector. Healthy urban fast food-a new Maasai enterprise. Point of impact. AVRDCThe World Vegetable Center, Tainan.

Bartlett, M. S. 1937. Some examples of statistical methods of research in agriculture and applied biology. J R Statist Soc. Suppl. 4:137-183.

Chan, K and M Sun. 1997. Genetic diversity and relationships detected by isozyme and RAPD analysis of crop and wild species of Amaranthus. Theoretical and Applied Genetics. 95(5-6): 865-873.

Fasuyi, A. O. 2007. Amaranthus cruentus leaf meal as a protein supplement in broiler finisher diets part 1. Performance and nitrogen utilization. African Journal of Food Agriculture Nutrition and Development. 7(6):1-15.

Grubben, G. J. H. 2004 Amaranthus cruentus L. In: Grubben GJH. Denton OA. (eds) Plant resources of tropical Africa 2. Vegetables. Backhuys Publishers, Wageningen, Pp. 67-72 
Oluoch, M. O., G. N. Pichop, D. Silue, M.O. Abukutsa-Onyango, M. Diouf, C.M Shackleton. 2009. Production and harvesting systems for African Indigenous Vegetables. In: Shackleton C.M, Pasquini, M. W, Drescher, A (eds). African indigenous vegetables in urban agriculture. Earth scan, London, UK, Pp. 145-175.

Johnson, HW, H. F. Robinson, R. E. Comstock. 1955. Estimates of genetic and environmental variability in soybean. Agron J 47: 314-318. http://dx.doi.org/10.2134/agronj1955.000 21962004700070009x.

Patro, TSK and Ravisankar, C. 2004. Genetic variability and multivariate analysis in okra [Abelmoschus esculentus (L.) Moench]. Tropical Agriculture Res 16: 99-113.

PospiŠil, A. PospiŠil, M. Varga, B. Svecnjak, Z. 2006. Grain yield and protein concentration of two amaranth spieces (Amaranthus spp.) as influenced by nitrogen fertilization. European Journal of Agronomy. 25: 250-253.

Poehlman, JM., and Sleper, DA. (1995). Breeding field crops (4th Ed.). Ames, IA: Iowa State University Press.

SAS. 2008. Statistical Analysis System, version 9.2. SAS Institute Inc. Cary, NC, USA.

Sharma, K., CS Semwal and SP Uniyal. 2010. Genetic variability and character association analysis in Bell pepper (Capsicum annuum L.). Journal of Horticulture and Forestry. 2: 058- 065.

Shukla, S and Singh, SP 2000. Studies on genetic parameters in vegetative amaranth Journal of Genetics and Breeding. 54: 133 - 135.

Shukla, S. Bhargam, A. Chatterju, B. and Singh, NP 2004. Estimate of genetic parameters to determine viability for foliage yield and the different quantitative and qualitative traits in vegetable amaranth (A. tricolor) Journal of Genetics and Breeding. 58: 169-176.

Singh, B. 2001. Plant Breeding: Principles and Methods, 6th ed., Kalyani Publishers, New Delhi, India.

Smith, F.I. and P. Eyzaguirre. 2007. African leafy vegetables: their role in the World Health Organization's global fruit and vegetables initiative. In: Oniang'o R, Grum M, ObelLawson E (eds) Developing African leafy vegetables for improved nutrition, Regional workshop, 6-9 December 2005, Rural Outreach Program, Nairobi, Kenya, Pp. 1-8.

Syukur, M., S. Sujiprihati and R. Yunianti. 2012. Teknik Pemuliaan Tanaman. Penebar Swadaya. Jakarta.

Syukur, M. and S. Rosidah. 2014. Estimation of genetic parameter for quantitative characters of pepper (Capsicum annuиm L.). Journal of Tropical Crop Science. 1: 4 -8 .

Trucco, F, P. J. Tranel. 2011. Amaranthus. In: Kole C (Ed). Wild crop relatives: genomic and breeding resources vegetables, vol XXVI. Springer-Verlag, Berlin Heidelberg, Pp. 11-21.

van Le, B, Jeanneau, M., Sadik S., Tu S., Vidal J., Tra ^n Thanh Va ^n K 1998. Rapid plant regeneration of a $\mathrm{C} 4$ dicot species: Amaranthus edulis. Plant Science. 132(1):45-54. doi:10.1016/S0168-9452(97)00262-8. 